\title{
THE HARVARD ORIENTAL SERIES
}

VOLUME THIRTY 


\section{HARVARD ORIENTAL SERIES}

EDITED

WITH THE COÖPERATION OF VARIOUS SCHOLARS

BY

\section{CHARLES ROCKWELL LANMAN}

Professor at Harvard University; Honorary Fellow of the Asiatic Society of Bengal, of France, of England, and of Germany; Corresponding Member of the Society of Sciences at Göttingen, the Russian Academy of Sciences, and the

Academie des Inscriptions et Belles-Lettres of the Institute of France

\section{Zolume Chírty}

\section{CAMBRIDGE, MASSACHUSETTS

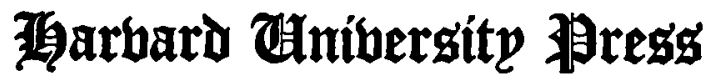

1921 


\section{BUDDHIST LEGENDS}

Translated from the original 3 Aali text of the

DHAMMAPADA COMMENTARY

BY

\section{EUGENE WATSON BURLINGAME}

Fellow of the American Academy of Arts and Sciences; sometime

Harrison Fellow for Research, University of Pennsylvania, and

Johnston Scholar in Sanskrit, Johns Hopleins University;

Lecturer on Pāli (1917-1918) in Yale University

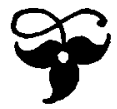

Part 3: Translation of Books 13 to 26

CAMBRIDGE, MASSACHUSETTS

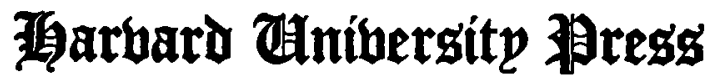

1921 
Volumes 28 and 29 and 30, first issue : 1000 copies each Copyright, 1921, by the Harvard University Press

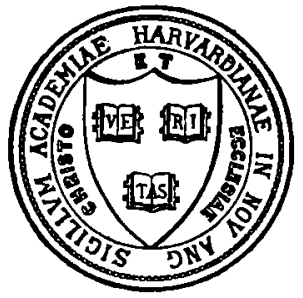

Composed on the monotype, and printed from electrotype plates, by The University Press : John Wilson \& Son, Incorporated, Cambridge, Massachusetts, U.S.A. 